Jacek BONAREK*

\title{
ROLA NIKEI JAKO CENTRUM BIZATYŃSKIEGO ŚWIATA PO 1204 ROKU
}

Po burzliwych wydarzeniach z kwietnia 1204 r. i po przejściu władzy w Konstantynopolu w ręce łacinników, Nikea przejęła - w popularnym rozumieniu - rolę centrum politycznego, duchowego i kulturowego postbizantyńskiego świata ${ }^{1}$. Proces ten wiąże się najczęściej z osobą Teodora Laskarysa (ok. 1174-1221/1222) ${ }^{2}$, a dowodem na to może być list Michała Choniatesa (ok. 1138 - ok. 1222), który zapewnia, że żaden basileus Miasta [tj. Konstantynopola] nie dorównuje Teodorowi Laskarysowi, z wyjątkiem Herakliusza (ok. 575-641) i Bazylego (958-1025)3. Mimo że trudno zaprzeczyć prawdzie powyższych słów, gdyż $\mathrm{w}$ istocie Nikea pod rządami basileusów z rodu Laskarysów stała się symbolem niezależności romejskiego świata w 1. poł. XIII wieku ${ }^{4}$, to jednak warto pamiętać, iż rola Nikei oraz znaczenie w dziejach tego miasta założyciela dynastii Laskarysów ${ }^{5}$ nie są tak proste oraz jednoznaczne.

${ }^{*}$ Dr hab. Jacek Bonarek - adiunkt w Zakładzie Historii Powszechnej do XIX wieku i Historii Historiografii na Wydziale Filologiczno-Historycznym Uniwersytetu Jana Kochanowskiego w Kielcach, Filia w Piotrkowie Trybunalskim; e-mail: j.bonarek@unipt.pl.

${ }^{1}$ Por. G. Ostrogorsky, Geschichte des Byzantinischen Staates, München 1963, 353-354; J. Godfrey, 1204. The Unholy Crusade, Oxford 1980, 157; C. Foss - J. Tulchin, Nicaea: a Byzantine capital and its praises: with the speeches of Theodore Laskaris, In praise of the great city of Nicaea, and Theodore Metochites, Nicene oration, Brookline (Mass.) 1996, 57; P. Krupczyński, Nikea, w: Encyklopedia kultury bizantyńskiej, red. O. Jurewicz, Warszawa 2002, 370-371; É. Patlagean, Un Moyen Âge grec. Byzance IX ${ }^{e}-X V^{e}$ siècle, Paris 2007, 291.

${ }^{2}$ Por. Ostrogorsky, Geschichte, s. 352; M. Angold, A Byzantine Government in Exile: Government and Society under the Laskarids of Nicaea, 1204-1261, Oxford 1975, 1; tenże, The Fourth Crusade. Event and Context, Harlow 2003, 193 i 197; C. Morrisson, Czwarta wyprawa krzyżowa i nowa organizacja polityczna (1204-1258), w: Świat Bizancjum, t. 3: Bizancjum i jego sasiedzi 1204-1453, red. A. Laiou - C. Morrisson, thum. A. Graboń, Kraków 2013, 15.

${ }^{3}$ Por. Michael Choniates, Epistulae 179, ed. F. Kolovou, Corpus Fontium Historiae Byzantinae (= CFHB) 41: Series Berolinensis, Berlin - New York 2001, 284-285. Zob. J. Haldon, Bizancjum. Zarys dziejów, tłum. Z. Simbierowicz, Warszawa 2006, 44-45.

${ }^{4}$ Por. Ostrogorsky, Geschichte, s. 353; H. Ahrweiler, L'expérience nicéenne, DOP 29 (1975) 24; M.J. Leszka, Nicea - tymczasowa stolica Bizantyńczyków, „Piotrkowskie Zeszyty Historyczne" 12/2 (2011) 211-220; tenże, Между Константинополем и Константинополем. Из истории столичного статуса Никеи в ХІІІ веке, „Balcanica Posnaniensia” 19 (2012) 39-49.

${ }^{5}$ Dość istotną kwestią są działania Konstantyna Laskarysa (ok. 1170-1205). Ów brat przyszłego władcy Nikei Teodora został proklamowany cesarzem w kwietniu 1204 r. w obleganym przez 
Niewątpliwie Nikea była predestynowana do odegrania istotnej roli jako naturalne centrum Bitynii ${ }^{6} \mathrm{i}$ jako, znany od starożytności, ważny ośrodek polityczny, będący kwaterą główną wojsk oraz dwukrotnym miejscem obrad soborów powszechnych ${ }^{7}$. Ponadto leżała w odległości około $70 \mathrm{~km}$ od Konstantynopola na przecięciu strategicznych dróg i liczyła 25-30 tys. mieszkańców8 ${ }^{8}$.

Jakkolwiek to ludne i bogate miasto, o szerokich i prostych ulicach, ozdobione takimi budowlami jak kościół Hagia Sofia (miejsce obrad I (325) i VII (787) soboru powszechnego) czy kościół Zaśnięcia NMP przy klasztorze Hiakintosa ${ }^{9}$, musiało uchodzić w powszechnym rozumieniu za centrum kulturowe i duchowe ${ }^{10}$ nowego państwa, nie jest jednak pewne, czy stało się jego stolicą sensu stricto $^{11}$.

łacinników Konstantynopolu. Nie potrafiąc jednak zorganizować władzy ani stawić oporu najeźdźcom, miał schronić się w Nikei. Jednakże w następnych latach nie zdołał wykorzystać swej pozycji, a ostatecznie rolę budowniczego sukcesyjnego państwa przejął Teodor Laskarys. Por. Nicetas Choniates, Historia, ed. J.A. van Dieten, CFHB 11: Series Berolinensis, Berlin - New York 1975, 572. Zob. П.И. Жаворонков, У истоков образования Никейской империи: (оценка деятельности Константина XI Ласкаря), „Византийский Временник” 38 (1977) 30-31; Z. Pentek, Cesarstwo Lacińskie 1204-1261. Kolonialne państwo krzyżowców czy Neobizancjum?, Poznań 2004, 67; C. Foss, Emperors named Constantine, „Revue Numismatique” 6 (2005) 90-99; Leszka, Nicea, 213 215. Na temat działalności Teodora Laskarysa w pierwszych latach jego rządów zob. Ostrogorsky, Geschichte, s. 352-355; I. Boot, Theodore Laskaris and Paphlagonia, 1204-1214: towards a chro-

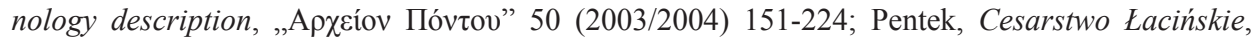
s. 90, 93 i 113-117; J. Bonarek, Separatyzm bizantyński w dobie IV krucjaty a działalność Teodora Laskarysa, „Piotrkowskie Zeszyty Historyczne” 9 (2008) 27-41; Leszka, Nicea, s. 214-215; tenże, Между Константинополем, s. 41.

${ }^{6}$ Warto jednak pamiętać, że mieszkańcy Nikei nie otworzyli przed Teodorem Laskarysem bram swego miasta i musiał on początkowo ustanowić swą siedzibę w Brusie; por. Georgius Acropolites, Historia 6, ed. A. Heisenberg, P. Wirth, w: Georgius Acropolites, Opera, t. 1, Stuttgart 1978, 10; Жаворонков, У истоков образования, s. 31-32; J.-C. Cheynet, Pouvoir et contestations à Byzance, Paris 1996, 469; Patlagean, Un Moyen Âge, s. 297 i 307; Leszka, Nicea, s. 213-214; tenże, Междy Константинополем, s. 41-42.

${ }^{7}$ Por. R. Janin, Nicée. Étude historique et topographique, EO 28 (1925) 482-487.

${ }^{8}$ Por. П.И. Жаворонков, Малоазийские города периода Никейской империи, „Античная Древность и Средние Века" 25 (1990) 56; tenże, Культура Никейской империи, w: Культура Византии XIII - первая половина XV в., red. Г.Г. Литаврин, Москва 1991, 46.

${ }^{9}$ Por. Janin, Nicée, s. 489-490; М.А. Андреева, Очерки по культуре византийского двора в ХІІІ в., Прага 1927, s. 21; Жаворонков, Малоазийские города, s. 58; tenże, Культура Никейской империи, s. 46 і 47; Foss - Tulchin, Nicaea, s. 101-120; E. Concina, La città bizantina, Roma - Bari 2003, 143; Leszka, Nicea, s. 218, nota 37; tenże, Между Константинополем, s. 45, nota 37.

${ }^{10}$ Świadczyć mogą o tym mowy pochwalne na cześć Nikei ułożone przez najwybitniejsze postacie życia umysłowego tamtych czasów: Teodora II Laskarysa oraz Teodora Metochitesa (12701332), por. Foss - Tulchin, Nicaea, s. 132-153 і 164-195. Zob. Жаворонков, Культура Никейской империи, s. 46; D. Angelov, Imperial Ideology and Political Thought in Byzantium, 1204-1330, Cambridge 2007, 169.

${ }^{11}$ Wprawdzie Gotfryd de Villehardouin (1150/1164 - ok. 1213; La conquête de Constantinople par Geoffroi de Ville-hardouin avec la continuation de Henri de Valenciennes 455, ed. M. Natalis de Wailly, Paris 1872, 272, thum, Z. Pentek: Geoffroy de Villehardouin, Zdobycie Konstantynopola, Po- 
Potwierdzać ten fakt zdawałaby się działalność samych władców Nikei, którzy bardzo dbali o wizualną stronę największego miasta w swoim państwie $^{12}$. Wiadomym jest na przykład, że Teodor I odnowił mury miejskie ${ }^{13}$, których drugi krąg wniósł następnie Jan III Dukas Watatzes (ok. 1192 -1254) ${ }^{14}$. Ten cesarz miał też być inicjatorem budowy klasztoru św. Antoniego Wielkie$\mathrm{go}^{15}$. Działalność budowlaną Jana Watatzesa podkreśla mocno w jednym ze swych wierszy Nikefor Blemmydes (ok. 1197 - ok. 1272), który wprost mówi, że cesarz niezmiernie upiększył Nikeę ${ }^{16}$.

Szczególnego znaczenia nabiera tu - i jednocześnie pozwala zastanowić się nad statusem Nikei - fakt, że jest to wiersz na cześć klasztoru Sosandra ${ }^{17}$ wzniesionego w okolicach Magnezji, czyli terenów o wiele bardziej przez ród

znań 2003, 173) w swym dziele określa Nikeę jako centrum ziem Teodora Laskarysa - co naturalnie można zrozumieć jako stolicę - i podobnie też czyni w swym panegiryku na cześć Teodora Laskarysa Niketas Choniates (Nicetas Choniates, Orationes et epistulae 14, ed. J.A. van Dieten, CFHB 3: Series Berolinensis, Berlin - New York 1972, 139; por. Leszka, Nicea, s. 215), to jednak inne źródła bizantyńskie, wspominając Nikeę, najczęściej nie podkreślają tak wyraźnie jej szczególnego znaczenia. Np. Jerzy Akropolites (Historia 52, 53 i 77, ed. Heisenberg - Wirth, t. 1, s. 101, 106 i 159) wprawdzie określa Nikeę mianem najważniejszego miasta - ale Bitynii, z kolei Jerzy Pachymeres (1242 - ok. 1310; Georgius Pachymeres, Relationes historicae I 2, ed. A. Failler - V. Laurent, CFHB 24/1: Series Parisiensis, t. 1, Paris 1984, 25) wydaje się stawiać na równi trzy miasta: Nikeę, Brusę oraz Filadelfię. Metropolitarny (stołeczny) charakter Nikei jako miejsca wyboru na cesarza Teodora Laskarysa można natomiast dostrzec w dziele Nikefora Gregorasa (1295 - ok. 1360; Nicephorus Gregoras, Byzantina historia I 2, 1, ed. L. Schopen, Corpus Scriptorum Historiae Byzantinae (= CSHB) 19/1, Bonn 1829, 13 = PG 148, 132B).

${ }^{12}$ Jednak ich budowlana działalność jest trudna do uchwycenia, gdyż w przypadku topografii Nikei opierać należy się głównie na rozproszonych informacjach źródłowych, jako że współczesne İznik (Nikea) w niewielkim stopniu odzwierciedla układ miasta z czasów bizantyńskich, por. Жаворонков, Культура Никейской империи, s. 46; Concina, La città, s. 139-144.

${ }^{13}$ Por. Angold, A Byzantine Government, s. 99; Жаворонков, Малоазийские города, s. 56-57; tenże, Культура Никейской империи, s. 48; Foss - Tulchin, Nicaea, s. 93; G. Kiourtzian, L'époque protobyzantine à travers les monuments épigraphiques, w: La Bithynie au Moyen Âge, ed. B. Geyer - J. Lefort, Paris 2003, 58; Leszka, Nicea, s. 216 i 218; tenże, Между Константинополем, s. 45.

${ }^{14}$ Por. Foss - Tulchin, Nicaea, s. 93 i 94-95; Leszka, Nicea, s. 216 i 218; tenże, Междy Константинополем, s. 45.

${ }^{15}$ Por. Nicephorus Gregoras, Byzantina historia II 7, 2, CSHB 19/1, 44 (= PG 148, 169B); Андреева, Очерки по культуре, s. 21; Angold, A Byzantine Government, s. 47-48; Жаворонков, Малоазийские города, s. 58; tenże, Культура Никейской империи, s. 46; Foss - Tulchin, Nicaea, s. 109; Concina, La città, s. 143.

${ }^{16}$ Por. Nicephorus Blemmydes, Curriculum vitae et carmina, ed. A. Heisenberg, Leipzig 1896, 113. Zob. Жаворонков, Культура Никейской империи, s. 46. Również w następnych latach władcy nikejscy nie zapominali o swym największym mieście, w którym syn i następca Jana III miał wznieść kościół św. Tryfona, por. Андреева, Очерки по культуре, s. 21; Жаворонков, Малоазийские города, s. 58; tenże, Культура Никейской империи, s. 47.

${ }^{17}$ Por. Nicephorus Gregoras, Byzantina historia II 7, 2, CSHB 19/1, 44 (= PG 148, 169A-B). Zob. H. Ahrweiler, L'histoire et la géographie de la région de Smyrne entre les deux occupations turques (1081-1317) particulièrement au XIII siècle, „Travaux et Mémoires” 1 (1965) 94-96; Angold, A Byzantine Government, s. 48; Жаворонков, Культура Никейской империи, s. 47 і 50-51; 
panujący w Cesarstwie Nikei poważanych niż sama Nikea ${ }^{18}$. To w tamtejszym klasztorze miały znajdować się grobowce Laskarysów ${ }^{19}$. W Magnezji został wzniesiony również jeden z pałaców cesarskich, z kolei drugi z inicjatywy Jana III Dukasa powstał w Nymfajonie ${ }^{20}$.

Ten ostatni ośrodek najprawdopodobniej już za panowania Teodora I zaczął odgrywać ważną rolę na kontrolowanych przez niego terenach ${ }^{21}$, pretendując nawet do roli stołecznego miasta ${ }^{22}$. Niewątpliwie Nymfajon stał się ulubioną rezydencją nikejskich władców, gdzie przyjmowano poselstwa i zawierano międzynarodowe traktaty ${ }^{23}$ oraz gdzie do godności cesarskiej został wyniesiony Teodor II Laskarys (ok. 1221-1258) ${ }^{24}$, a także Michał VIII Paleolog (ok. 1224-1282) ${ }^{25}$.

Polityczna rola Nikei nie jest więc tak jednoznaczna jak w przypadku Konstantynopola. Można w tym momencie zastanowić się, czy rekompensowała to metropolii jej pozycja centrum kultury i nauki Cesarstwa Nikejskiego. $\mathrm{Z}$ pewnością na tle innych postbizantyńskich państw nikejski ośrodek jaśniał, co było spowodowane faktem, że na ziemiach małoazjatyckich szukali schronienia najwięksi luminarze schyłku komneńskiego odrodzenia ${ }^{26}$.

E. Mitsiou, The monastery of Sosandra: a contribution to its history, dedication and localisation, „Bulgaria Medievalis” 2 (2011) 665-684.

${ }^{18}$ Magnezja leżała pomiędzy rzekami Hermus i Meander, które wyznaczały centrum gospodarcze nikejskiego państwa Romejów, por. M.F. Hendy, Studies in Byzantine Monetary Economy, c. 300-1450, Cambridge 1985, 443. Zob. Angold, The Fourth Crusade, s. 205-206.

${ }^{19}$ Por. Georgius Acropolites, Historia 74, ed. Heisenberg - Wirth, t. 1, s. 153. Zob. Жаворонков, Культура Никейской империи, s. 47; R. Macrides, Introduction, w: George Akropolites, The History, ed. R. Macrides, Oxford 2007, 87; Angelov, Imperial Ideology, s. 267; Mitsiou, The monastery of Sosandra, s. 665-666; Leszka, Между Константинополем, s. 44-45 i nota 33.

${ }^{20}$ Por. Жаворонков, Культура Никейской империи, s. 47-48. Zob. Ch. Bouras, Houses in

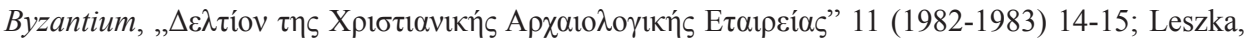
Nicea, s. 219, nota 46.

${ }^{21}$ Jakkolwiek z całą pewnością miasto to zyskało na znaczeniu za panowania Jana III Watatzesa, który traktował Nymfajon jako ulubioną rezydencję, por. Жаворонков, Малоазийские города, s. 57; tenże, Культура Никейской империи, s. 49 і 50; W. Treadgold, A History of the Byzantine State and Society, Stanford 1997, 719; Angold, The Fourth Crusade, s. 204; Macrides, Introduction, s. 87. Zob. C. Foss - J.A. Scott, Sardis, w: The Economic History of Byzantium, ed. A.E. Laiou, t. 2, Washington 2002, 620.

${ }^{22} \mathrm{Na}$ temat roli i znaczenia miasta por. Андреева, Очерки по культуре, s. 22; Ahrweiler, L' $h i$ stoire, s. 42-44; Hendy, Studies, s. 116 і 443; Жаворонков, Культура Никейской империи, s. 49 i 50. Zob. Angold, The Fourth Crusade, s. 204; Leszka, Nicea, s. 219.

${ }^{23}$ Jednym z najważniejszych był traktat zawarty w 1261 r. pomiędzy Nikeą a Genuą, mający pomóc Romejom uzyskać przewagę na morzu i w dalszej perspektywie odzyskać Konstantynopol, por. D.J. Geanakoplos, Emperor Michael Palaeologus and the West 1258-1282: A Study in Byzantine-Latin Relations, Cambridge, Mass. 1959, 81-91; M. Balard, La Romanie génoise (XII'-dèbut du XV siècle, t. 1, Rzym - Genua 1978, 42-45; tenże, Laciński wschód XI-XV w., thum. W. Ceran, Kraków 2010, 233.

${ }^{24}$ Por. Georgius Acropolites, Historia 53, ed. Heisenberg - Wirth, t. 1, s. 105.

${ }^{25}$ Por. Angelov, Imperial Ideology, s. 130.

${ }^{26}$ Wymienić można Niketasa Choniaesa (ok. 1155 - 1215/1217) czy Demetriosa Karykesa (ok. 
Edukacją oraz rozkwitem życia intelektualnego w swym państwie zainteresowani byli nikejscy basileusi ${ }^{27}$. $\mathrm{O}$ ile jednak miasta podległe ich władzy były w stanie zapewnić podstawowe wykształcenie ${ }^{28}$, o tyle w celu zyskania wiedzy na wyższym poziomie trzeba było niejednokrotnie podróżować do wybitnych uczonych ${ }^{29}$. Tym samym uzyskanie wyższego wykształcenia w państwie nikejskim było trudniejsze niż w cesarstwie przed rokiem 1204. W znacznej części stanowiło również wynik osobistych umów ucznia i nauczyciela ${ }^{30}$.

Kulturowa rola Nikei szczególnie widoczna była za panowania Jana III Dukasa Watatzesa i Teodora II Laskarysa. Zwłaszcza ten ostatni cesarz-uczony, wychowanek Nikefora Blemmydesa i autor mowy wysławiającej Nikeę miał uczynić z formalnej stolicy swojego państwa prawdziwy ośrodek naukowy poprzez powołanie szkoły przy kościele św. Tryfona ${ }^{31}$.

Nie wszyscy jednak ówcześni zgadzali się z wysoką oceną życia umysłowego Nikei. Jedną z tych osób był urodzony około 1241 r. na Cyprze Jerzy $(\dagger 1290)^{32}$. Ten wielki miłośnik wiedzy, nie mogąc znaleźć odpowiednich greckich nauczycieli w Kallinikisis (Nikozji) ani uzupełnić wykształcenia

1180 - po 1234), który jako konsul filozofów miał egzaminować na zakończenie studiów największego rodzimego uczonego świata nikejskiego Nikefora Blemmydesa (Autobiographia sive Curriculum Vitae necnon Epistula Universalior II 8-16, ed. J.A. Munitiz, CCG 13, Turnhout - Leuven 1984, 50-54). Zob. Андреева, Очерки по культуре, s. 139-140; Angold, A Byzantine Government, s. 179; Жаворонков, Культура Никейской империи, s. 54.

${ }^{27}$ Роr. Жаворонков, Культура Никейской империи, s. 74; Leszka, Nicea, s. 218-219; tenże, Между Константинополем, s. 45-46; В. Mondrain, Życie umysłowe, w: Świat Bizancjum, t. 3, s. 279.

${ }^{28}$ Wydaje się jednak, że ukazuje to problem rozproszenia nauki w Cesarstwie Nikei, gdzie brak było początkowo jednego wyrazistego edukacyjnego centrum, jakkolwiek już Teodor I Laskarys miał powołać do życia szkoły w części miast podległych jego władzy (Prusa, Nikea, Smyrna), por. Жаворонков, Культура Никейской империи, s. 74.

${ }^{29} \mathrm{Na}$ przykład wspominany już Nikefor Blemmydes (Autobiographia I 6, CCG 13, 5-6), aby uzupełnić swą naukę, musiał udać się do opanowanej przez łacinników Troady, gdzie mieszkał odpowiedni nauczyciel. Por. Angold, A Byzantine Government, s. 178; C.N. Constantinides, Higher education in Byzantium in the Thirteenth and early Fourteenth centuries (1204-ca.1310), Nicosia 1982, 8.

${ }^{30}$ Por. Mondrain, Życie umystowe, s. 280. Zob. Macrides, Introduction, s. 8. System prywatnej edukacji nie okazał się też najszczęśliwszy dla samych nauczycieli, czego doświadczył Nikefor Blemmydes (Autobiographia I 49-I 53, CCG 13, 27-29), który traktował bardzo surowo swoich uczniów i z tego powodu dwóch z nich, Roman i Krateros związało się z jego przeciwnikami, a Krateros oskarżył nawet nauczyciela o defraudację. Рог. Андреева, Очерки по культуре, s. 141.

${ }^{31}$ Por. Theodorus Scutariotes, Synopsis chronike, w: Messaionike Bibliotheke, ed. K.N. Sathas, t. 7, Paris 1894 [Reprint: Hildesheim 1972], 512; Андреева, Очерки по культуре, s. 21; Angold, A Bуzantine Government, s. 179-180; tenże, The Fourth Crusade, s. 209; Constantinides, Higher education, s. 19; Foss, Tulchin, Nicaea, s. 67-70; Leszka, Nicea, s. 219; tenże, Между Константинополем, s. 46.

32 Już jako wykształcony człowiek, u schyłku XIII w., został patriarchą Konstantynopola pod imieniem Grzegorza II Cypryjczyka (ok. 1240-1290, patriarcha w latach: 1283-1289). Por. V. Laurent, La chronologie de patriarches de Constantinople au XIII siècle, REB 27 (1969) 146-147; I. Pérez Martín, À propos des manuscrits copiés par George de Chypre (Grégoire II), patriarche de Constantinople (1283-1289), „Scriptorium” 46 (1992) 73-74. 
w szkołach łacinników ${ }^{33}$, wyjechał na tereny podległe Laskarysom. Jednakże, mimo że w istniejących tam szkołach zdobył upragnioną przez siebie wiedzę, to w swej autobiografii w niezmiernie ostrych słowach przedstawił realia nikejskiej edukacji ${ }^{34}$.

Najpierw, przytoczywszy opinię mieszkańców Efezu, skrytykował jednego z najbardziej wykształconych mieszkańców Cesarstwa Nikei - Nikefora Blemmydesa ${ }^{35}$. Wprawdzie nie negował jego wiedzy, ale przedstawił uczonego jako człowieka niedostępnego, dumnego i gardzącego biednymi ${ }^{36}$. Następnie odmalował w ciemnych barwach poziom nauczycieli w samej Nikei. Zgodnie z jego słowami nikejczycy byli w stanie uczyć jedynie gramatyki i poetyki. Retoryki i filozofii, jak i innych nauk, uczyć nie mogli, bowiem ani nie mieli odpowiedniej wiedzy, ani nawet o tych dziedzinach nie słysze$\operatorname{li}^{37}$. Szczęściem dla świata i ludzi pragnących wykształcenia Michał Paleolog odzyskał Konstantynopol i nauka mogła się tam rozwijać, kierowana przez Jerzego Akropolitesa (1217-1282) ${ }^{38}$.

Zarzut wysuwany przez Jerzego z Cypru wobec poziomu nauki w Nikei odnosi się również do szkoły wyższej założonej przez Teodora II Laskarysa, który wprawdzie nakazał nauczać gramatyki, poezji, retoryki i filozofii, ale pomimo specjalnego funduszu i finansowego wsparcia cesarza liczba uczniów była niewielka ${ }^{39}$.

${ }^{33}$ Por. Georgius Cypriensis, Particularis historiae sermo, PG 142, 21A-B. Zob. Constantinides, Higher education, s. 25.

${ }^{34}$ Por. Georgius Cypriensis, Particularis historiae sermo, PG 142, 21D - 25B. Notabene rozpoczynając narrację o swoich peregrynacjach w celu zdobycia wiedzy, wyraźnie zaznaczył, że w czasach Teodora II Nikea pod względem poziomu wiedzy była porównywana do starożytnych Aten (por. tamże, PG 142, 21D). Zob. Андреева, Очерки по культуре, s. 20; Constantinides, Higher education, s. 25; Жаворонков, Малоазийские города, s. 60; Foss - Tulchin, Nicaea, s. 70.

${ }^{35}$ Nikefor Blemmydes urodził się w 1197 r. w Konstantynopolu, lecz dorastał i zdobywał wykształcenie jako uchodźca w Azji Mniejszej, gdzie studiował m.in. medycynę, filozofię i teologię. Jednak i Nikefor jako mnich opuścił Nikeę, by osiąść w pobliżu Efezu, gdzie kontynuował nauczanie. Jego najsławniejszymi uczniami byli Teodor Laskarys i Jerzy Akropolites, por. Андреева, Очерки по культуре, s. 128-129; Angold, A Byzantine Government, s. 178; tenże, The Fourth Crusade, s. 208-209; Constantinides, Higher education, s. 7-8; Жаворонков, Культура Никейской империи, s. 54-58; Angelov, Imperial Ideology, s. 65.

${ }^{36}$ Por. Georgius Cypriensis, Particularis historiae sermo, PG 142, 24B-C. Zob. Андреева, Очерки по культуре, s. 140; Constantinides, Higher education, s. 25.

${ }^{37}$ Por. Georgius Cypriensis, Particularis historiae sermo, PG 142, 24D - 25B. Zob. Андреева, Очерки по культуре, s. 129 і 168; Angold, A Byzantine Government, s. 178; Constantinides, Higher education, s. 26.

${ }^{38}$ Por. Georgius Cypriensis, Particularis historiae sermo, PG 142, 25C-D i 28A-C. Zob. Constantinides, Higher education, s. 32; П.И. Жаворонков, Личность и творчество Георгия Акрополита, w: Георгий Акрополит, История, перевод, вступительная статья и приложения П.И. Жаворонков, Санкт-Петербург 2005, 21; Angold, The Fourth Crusade, s. 212.

${ }^{39}$ Por. Андреева, Очерки по культуре, s. 133-134; Angold, A Byzantine Government, s. 179-180. 
Próba ustanowienia jednego centrum edukacji w Nikei została więc podjęta praktycznie w końcu istnienia tego państwa ${ }^{40}$, wcześniej bowiem - jak już zostało wspomniane - wyższy etap edukacji był rozproszony i oddany W prywatne ręce. Początkowo zresztą basileusi nie starali się takiej sytuacji zaradzić i Jan III Watatzes również kontentował się wysyłaniem uzdolnionej młodzieży do prywatnych nauczycieli. I tak na przykład Jerzy Akropolites notabene urodzony w Konstantynopolu - wraz z czterema towarzyszami znalazł się w otoczeniu Teodora Heksapterygosa, wychowanka szkoły patriarszej w Konstantynopolu, aby dokształcić się w retoryce ${ }^{41}$. Natomiast po śmierci nauczyciela udał się do Nikefora Blemmydesa, przebywającego wówczas w klasztorze św. Grzegorza Cudotwórcy nieopodal Efezu, uzupełniał wiedzę w zakresie filozofii, korzystając z cesarskiego wsparcia ${ }^{42}$.

Nikea z pewnością pozostaje symbolem niezależności państwa Romejów w zachodniej części Azji Mniejszej po burzliwych wydarzeniach 1204 r., chociaż jej pierwszorzędna ranga przez całe półwiecze istnienia państwa Laskarysów nie jest jednoznaczna. Niewątpliwie w pierwszych latach po zdobyciu Konstantynopola przez łacinników, kiedy powszechnie oczekiwano na szybkie odzyskanie Miasta ${ }^{43}$, istotna mogła być bliskość Nikei w stosunku do utraconej stolicy ${ }^{44}$. Wydaje się jednak, że w końcu panowania Teodora I oraz za pano-

\footnotetext{
${ }^{40}$ Warto jednak podkreślić, że Teodor II, podejmując swe wysiłki, nie miał pojęcia o fakcie, że za kilka lat stolicą Cesarstwa ponownie będzie Konstantynopol i dlatego też jego działania można uznać za przejaw długofalowej polityki nikejskich władz.

${ }^{41}$ Por. Georgius Acropolites, Historia 32, ed. Heisenberg - Wirth, t. 1, s. 49. Zob. Андреева, Очерки по культуре, s. 118; Angold, A Byzantine Government, s. 179; Constantinides, Higher education, s. 9-10; Жаворонков, Культура Никейской империи, s. 63; tenże, Личность и творчество, s. 6-17.

${ }^{42}$ Por. Georgius Acropolites, Historia 32, ed. Heisenberg - Wirth, t. 1, s. 50. Zob. Angold, A Byzantine Government, s. 179; Жаворонков, Личность и творчество, s. 17.

${ }^{43}$ Por. Ahrweiler, L'expérience nicéenne, s. 25. Zob. Angold, The Fourth Crusade, s. 199-200.

${ }^{44}$ Niewątpliwie jawiła się ona jako dogodna do prowadzenia działań przeciwko zachodnim agresorom (por. Leszka, Nicea, s. 214; tenże, Между Константинополем, s. 42), aczkolwiek nie należy też zapominać, że wybór miejsca był wówczas dla Laskarysów mocno ograniczony ze względu na istniejące i powstające na tych terenach konkurencyjne państewka: Teodora Mankafasa (ok. 1188 1205) w Filadelfii, Manuela Maurozomesa († ok. 1230) oraz Nikefora Kontostefana (1. poł. XIII w.) w dolinie Meandra, Sabbasa Asidenosa (floruit: 1204-1216) na wybrzeżu wokół Sampson-Prieny i wreszcie w Paflagonii Dawida Komnena (1184-1214), który zdołał w 1205 r. ustalić granice swego państwa na rzece Sangarios (pominąć można Alderana w Attalli czy Leona Gabalasa (panował ok. 1203 - ok. 1240) na Rodos, gdyż te dwa ostatnie ośrodki z racji położenia musiały początkowo wzbudzać mniejsze zainteresowania Laskarysów). Zob. P. Orgels, Sabbas Asidénos, dynaste de Sampsôn, „Byzantion” 10 (1935) 67-80; Р. Радић, Обласни господари у Византији крајем ХІІ и у првим деценијама ХІІІ века, „Зборник радова Византолошког института” 24-25 (1986) 277-279; O. Lampsidis, La rivalité entre l'état de Grands Comnènes et celui de Nicée à propos de l'héritage de l'idée
} 
wania Jana III Watatzesa rola Nikei uległa redukcji na rzecz innych ośrodków, zwłaszcza Nymfajonu ${ }^{45}$ i Magnezji. Tendencja ta mogła zostać odwrócona za rządów Teodora II Laskarysa, który starał się w istocie uczynić z Nikei centrum swojego państwa ${ }^{46}$, jednak już kilka lat później Romejom udało się odzyskać Konstantynopol i sytuacja w świecie wróciła do naturalnego stanu rzeczy.

\section{THE ROLE OF NIKAIA AS THE CENTRE OF BYZANTINE WORLD AFTER 1204}

(Summary)

After the turbulent events of 1204 and after gaining the power by the Latins in Constantinople, Nicaea was supposed to become the center of post-Byzantine world as the capital of a country newly created by Theodore I Laskaris. It definitely fulfilled all the conditions to become the most significant town in the north-western part of Asia Minor. The sovereigns from the Laskaris dynasty supported its development as well, although it must be emphasized that it was not the only center of their country. Next to Nicaea both Magnesia and Nymphaion need to be mentioned. Nicaea became an important cultural and scientific center of the new empire. Nevertheless, it was not an exceptional place as the distinguished representatives of Byzantine scientific and cultural world lived also permanently in other towns (also in those towns which were under the Latins' rule). What is more, the educational system of Nicaea was criticized (e.g. George - Gregory II of Cyprus). The last but one emperor, Theodore II Laskaris (1254-1258), tried to make Nicaea the only center of Byzantine Greeks country. Nevertheless, as early as three years after his death the Byzantine Greeks regained Constantinople, the real capital of the world, and Nicaea again became the center of secondary importance.

Key words: Nicaea, the Laskaris dynasty, Magnesia, Nymphaion.

Słowa kluczowe: Nikea, dynastia Laskarysów, Magnezja, Nymfajon.

byzantine, w: Actes du XV Congrès International d'Études Byzantines, Athènes, septembre 1976, t. 4, Athènes 1980, 186-191; J.-C. Cheynet, Philadelphie, un quart de siècle de dissidence, 1182-1206, w: Philadelphie et autres études, Paris 1984, 39-54; П.И. Жаворонков, Никейско-трапезундские отношения в 1213-1223 г2., „Византийские Очерки” 1982 183-190; J. Bonarek, Sytuacja Cesarstwa Bizantyńskiego w przededniu IV krucjaty, w: IV krucjata. Historia. Reperkusje. Konsekwencje, red. Z.J. Kijas - M. Salamon, Kraków 2005, 41-43; С.П. Карпов, История Трапезундской империи, Византийская Библиотека. Исследования, Санкт-Петербург 2007, 84-111.

${ }^{45}$ Michael Angold zasugerował, że Watatzes przeniósł cesarską siedzibę do Nymfajon, aby uniknąć zatargów z patriarchą (Angold, The Fourth Crusade, s. 204).

${ }^{46}$ Warto podkreślić jednak, że Teodor II Laskarys reprezentuje nieco inny typ postbizantyńskiego człowieka, dla którego odzyskanie Konstantynopola i powrót do sytuacji sprzed 1204 roku były celami najważniejszymi, lecz nie za wszelką cenę. Rozwój i dobrobyt państwa nikejskiego wydają się być dla niego równie istotne i ważne, por. Ahrweiler, L'Expérience nicéenne, s. 32-33. 